\title{
大日本窯業協 會稚誌
}

\section{第三拾九 集 第四百六十三號}

(昭和六年 七 月)

(昭 和 六 年 月

此 の危 機を救 へ
一會員總動員 時代一

紫水生

旱天に惱む編輯室 本誌 6 月號、原稿悐雨なる題目の會告に於て、「月々の寄稿は全會員の百が一にすぎず」 及び「日照り續きの編輯窒に向ひ原稿の慈雨を降り注ぎ給はんことを願上候」と、編輯部員諸君は、極めて哀願 的な態度で普く全國會員に向つて原稿を求めてるる。責任ある編輯役員の言葉として、一點の疑ひの餘赦もあ るまい。

協會に於ける雜誌の重要性一體、我が協會の事業とは何か。叉數ある事業中最も重要性圶帶びるもの は何か。此所で試みに、本協會定款の第四條を一瞥しやう。

第四條 本會は第一條の目的(哭業の進步發達を圖るを以て目的とす)を達成する篇めに左の事業を行ふ。

一、雜誌又は圖書の刊行

二、調查、政究、建議、公共事業の助長

\section{三、講演會及講㕷會の開催}

四、其他必要なりと認むる事業

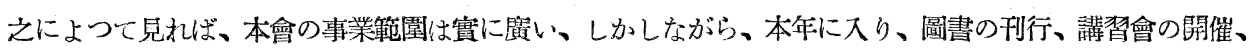
其他調查、硼究等の苴行されたことをまだ一度も耳にしない、講演會は只一度行はれただけである。かろ吟崃 して來ると、本會の事業として殘されるものは雜誌の發行だけではないか。而も之は每月の仕事ではないか。 墨業協會雜誌は本會の中心事業なりといつても敢て過言ではあるまい。更に私は、昭和五年度會務報告から引 用したい。其の經常費收支計算書の支出之部の示寸ところに依ると、雜誌發行に㴗する費用 $6,243.32$ 圓に對 し、其他の事業費は僅かに 65574圓、正に前者の1/10 にしか過ぎない。然る特は、本會に於汁る維誌發行事 業が如何に重要性を持つかといふことに就き愈㺘信を抱くのである。實に雜誌は本會の中心的事業である。そ して此の雜誌は主として全國に散在する會員諸君の原稿があつてこそ始めて生れるのである。原稿無き雜誌を 吾々は考ふることは出來妨とところが本誌編輯部は日照り續きなる交字によりて、編輯棚に原稿の空つぽにな つたことを傅へてみる。之をしも編輯部の危機といはずして何ぞやだ。而して、此の危機はやがて次第に榮譽 まる大日本筧業協會を伦機に導くものではないのか。 
筆不精は自慢にならぬ 吾々會員が每月始めに手にする雜誌は大略論說、報交、資料、雜錄、雜報、會 報等上り成つてるる。その中抄錄は抄錄委員團の手になるわので山り、雜報、會圉は編輯委員諸君の專ら菟集編 纂する處のものである、だから今吾々が原稿拂底の叫びを聞くも之は報文、論說、資料、雜錄に關する原稿の 缺乏を物語るものであらねばならぬ。一體 1,395 名 (昭和6年 3 月 31 日現在) の會員中唯の一人も、本邦化學工 業乃至空業の發展策について、是非黑白の議論はないるのか。不景氣の故に砰究室の活動も中止の狀態となり 從つて研究報告文の作製も不可能になつたといふ心のか。意氣消沈して外國文獻上り參考資料を集める元氣もな くなつたといふのか。さては製造人、貿易業者、學生、繁師何れも、各自の日常當面の仕事に對し、又は本誌 に對して善かれ惡しかれ何等の感想もないといふののか。上の事何れも覓なりとすれば筆者私は㕵然として何 等云ふ處を知らないであら弓。然し事の眞相は恐らく斷じて否である。私はさう信ずる。學者、技師何れも人 間である以上、性格も亦十人十色である。實驗の完成を今や抢そしとそれぞれの機關に發表を急ぐ笔まめの人 もあらら、よき報告材料を山と積みながら所謂筆不精のために、もたら世の尊き寶を持ち腐らす人もあらう。 勿論私は前者の型の人々に對しては交句はない。がしかし有能なれども笔不精の人に對しては大いに交句があ る。價值ある發見をして一人悅に入るのもよかららが、さして祕密にせ㰠でもよいものならば、どしどしその 美味を均しく世人に分配することは出來㰠ものか。政に食はれて、投稿規約に束縛されて、原稿紙の穴を一字

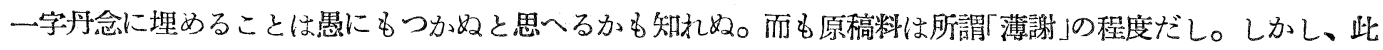

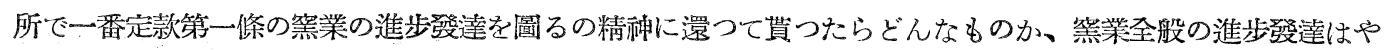
がてその個人の身を浮ばせる所以でをるのだから。

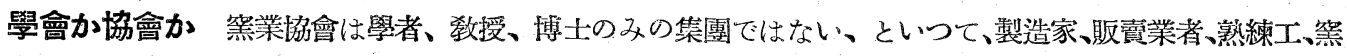
業學生の々の集團でもない。この事は會員業務別を見れば、一目瞭然たるものがある。第一項陶磁器製造に從 事する者 335 名より、第十一項直接篣業に關係なき者 50 名に至る會計 1,395 名の儎業上の分析は正しく吾々 に我が䳐業協會が、水は酸素と水素とより成り云々といふやうな、そんな單純な組成でないことがわかるので

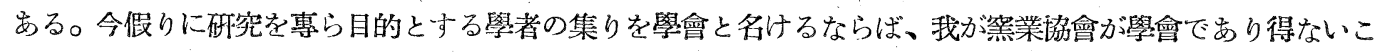
とは以上に證明した通りである。もつと適切にいふならば、本協會は一部分は學會であり、一部分は協會であ り、そして他の一部は學會と協會とを搗きまぜた形のものかも知れぬ。否もつと銃き洞察力を以てすれば、更 に更に複雜な組成を持つたものかも知れぬる

雜誌の內容は多方面であれ，前項に述べたるが如き職業別分析は、本協會の中心的事業たる椊誌の內容 如何を決定する。數式入りの報交に頭のうづき出す墨業商人は報交一點張りの雜誌には要無しとて、ポンと投 り出すであらら。班瑯關係の記事が何時まで待つても出て来娃、其の方面の會員はむつさりと退會して行く であらう。敎授、學徒は難しき報交を求め、墨業呚育者は教育上の記事を要望するであらら、其他云々。から考 えて來ると雜誌の獻立は非常に複雜したものになつて來る。デパート式內容を備へることを必要として來る。 でなければ現在の會員數を維持し、且入新しく會員を增加さすことは絕對不可能である。

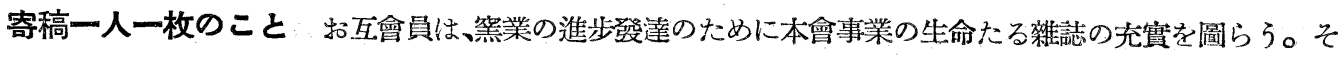
のためには、各自の從事せる業務の生活記錄を旱天に惱む編輯窒に投げつけやうではないか、報交よし、論說 よし、雜錄も可、感想も亦可。原稿用紙枚數の多少、交章の巧拙はさ万やかましく云ふ必要はあるまい。雜誌 編輯部の危機！正に會員總動員でペンを把る秋ではあるまいか、敢えて諸君に檄す。 